KoRSÓSNÉ DELACASSE Krisztina

DOI: 10.15170/DIKE.2020.04.01.08

adjunktus

PTE ÁJK

\title{
„Hogy karunk érdekeinek emelésére az egyesek nemes szándéka és tettereje egyesüljön” A budapesti ügyvédség testületté szerveződése a 19. században
}

\begin{abstract}
"To unite the noble intentions and vim of individuals to raise the interests of our faculty". The corporate organization of the lawyers of Budapest in the 19th century

The corporate organization of Hungarian lawyers began in the first half of the $19^{\text {th }}$ century, when lawyers realized that together they could work more effectively to raise their moral and professional esteem, and to reform the rules that applied to them. The most active in the country in this field were the lanyers of Budapest, who, after several antecedents, founded the Budapest Lanyers' Society in 1865-67. The goals of the society included the maintenance of moral credit and authority, the promotion of academic qualification, the development of legal knowledge, the identification of judicial shortcomings, the contribution to the uniform development of domestic legal life, as well as the assistance of members in need, their widows and orphans. The society was abolished in 1875 to give place to the Budapest Bar Association, established by Act No. 34 of 1874.
\end{abstract}

Keywords: $19^{\text {th }}$ century, Hungarian lawyers, faculty of lawyers, lawyers' associations, Budapest Lawyers' Society, Budapest Bar Association, Code of Conduct of Lanyers

\section{Ajánlás}

Kajtár István indított el egy olyan terület felé, amelyet a legrövidebben úgy fogalmaznék meg, az ügyvédség magyarországi történetének kutatása. A javaslata logikusnak tűnt, hiszen korábban egy másik jogászi hivatásrend, az ügyészség létrejöttét vizsgálva már elvetődtem e környékre. Mindenki tudja, akinek már része volt benne, hogy bármely kutatói feladat voltaképpen egy soha véget nem érô folyamat. Az ember megpróbálja áttekinteni a végtelen rónaságnak azt a szeletét, amelyet művelésre kijelöltek számára, vagy amelynek művelését maga választotta; olykor fűszálról fúszálra haladva megkísérel valami olyasmit begyüjteni, amivel korábban még senki nem találkozott, vagy legalább az összegereblyézett szálakból rendet rakni, a kazalból kiválogatni, ami értékes. Olykor aratásra is sor kerül, de a szorgos munka sem hozza meg feltétlenül mindig a várt termést. Néha azonban leszakítható egy-egy szép, érett gyümölcs - ilyennek tekintem az ügyvédi kamarák megalakulásával foglalkozó doktori disszertációmat is, amelyet az ő témavezetésével készítettem el. Emlékszem esetekre, amikor felhívta a figyelmemet, ha szerinte néhány történész vagy jogász kolléga is ezen a réten kaszált (vagy ahogyan ő szerette mondani: belekaszált a rétembe). Magam ugyan soha nem tekintettem e földet kizárólag a sajátomnak, és egy ideje más térség felfedezését tûztem ki célul, az ember természetesen soha nem tud teljesen elszakadni egy valamikor múvelt, jól 
megismert területtől és néha maga keresi fel újra, máskor pedig külső késztetések hatására tesz ismét látogatást a rég látott vidéken. Ilyen volt ez év elején a Budapesti Ügyvédi Kamara megtisztelő felkérése is, hogy tartsak előadást a megalakulás 145. jubileuma alkalmából tartott ünnepi ülésükön. ${ }^{1}$ Erre készülve ismét ellátogattam egykori „kiskertembe”, ami ugyan komoly termést ennyi év „elhanyagoltság” után nem ígért, de némi „talajrendezést”, „újraásást” követően mégis sikerült egy apró új virágocskát leszakítanom. Ezt szeretném most István emlékének ajánlani.

\section{Az ügyvédeket érő kritika és ennek lehetséges okai}

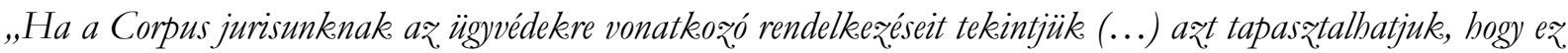

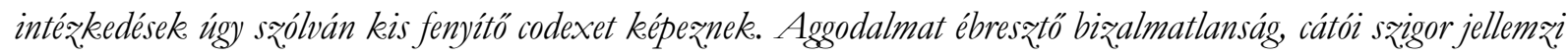
azokat, az ügyvédek minden képzelhetö visszaélései ellen irányozva, kötelességek és büntetések hosszu sorozatát képezik azok, de az ügyvédi magasabb érdekeek, az ügyvédek, jogainak biz̨tositása iránt a felekekel és biróságokekal szemben, e törvényekben vajmi kevés gondoskodást találunk.” - vélekedett Sárkány József 1875. február 20án a Budapesti Ügyvédi Kamara alakuló közgyülésén. ${ }^{2}$

A történelem során az ügyvédeket számos kritika érte, amelyeket nem egyszer törvényeink is ismételtek. Felmerül a kérdés, vajon hogyan lehet elkerülni, hogy az ügyvédségről a közvélemény negatív képet fessen. Tudtak-e, tudnak-e tenni maguk az ügyvédek bármit ezzel szemben, s ha igen, hogyan? Néhány válasszal már a 19. század is szolgálhat.

Hans Liermann az ügyvédek múltbéli rossz megítélését több okra vezeti vissza. ${ }^{3}$ A közvélemény egyrészt elvárja az ügyvédtől, hogy ügyfelét minél eredményesebben képviselje, másrészt viszont ugyanezt fel is rója: erkölcstelen az igazságszolgáltatásban az a szereplő, aki nem pártatlan. Ráadásul az ügyvéd hivatásszerűen és ellenérték fejében foglalkozik mások jogi természetű ügyeivel, ami a laikusokban úgy csapódhat le, hogy saját tudásbeli fölényéből vagy mások hozzá nem értéséből húz hasznot, s ezt néha pénzéhségnek állítják be. Amikor pedig az ügyvéd a büntető eljárásban védelmet lát el, úgy tekintenek rá, hogy egy kicsit maga is „,részese lesz” védence „bűnének” (arról nem is beszélve, hogy sokakban eleve az a képzet él, hogy a terhelt mindig bűnös). Ezek a sztereotip általánosítások sok kárt okoztak az ügyvédségnek, mint ahogyan az is, ha valamely ügyvéd valóban nem felelt meg mindazoknak az erkölcsi követelményeknek, amelyek betartását tőlük elvárták, a közvélekedés pedig kiterjesztette ezek megítélését az egész ügyvédségre.

Már I. Lipót 1694-ben kiadott királyi rendelete megkülönböztetett jó és rossz ügyvédet, s utóbbiakról azt írta: ezek vetnek rossz fényt az egész tiszteletreméltó karra, az olyanok, akik nyereségvágyból vegyesen vállalják a jogos és jogtalan igények érvényesítését, megbízóikat a hamis pervitelre okítják, netán olyanok, akiknek sem kellő jogtudásuk, sem kellő lelkiismeretük nincs. A 17. század végéig azonban nem mindig volt könnyű eligazodni, vajon milyen elvárásoknak feleljen meg az ügyvéd. Bár Magyarországon a már szinte hivatásszerűen felek perbeli képviseletével foglalatoskodó jogászi réteg kialakulása kb. a 15. század végére, a 16. század elejére tehetô, amikorra

\footnotetext{
${ }^{1}$ A tanulmány alapjául részben a 145 éves Budapesti Ügyvédi Kamara ünnepi elnökségi ülésén 2020. március 2-án elhangzott előadás szolgált, amelynek egy rövidített változata várhatóan a Pesti Ügyvéd hasábjain is megjelenik.

2 A Budapesti Ügyvédi Kamara Közgyúlésének jegyzőkönyvei, 1875. 02. 20. (A teljes ünnepi beszédet idézi: KORSÓSNÉ, Az ügyvédi kamarák megszületése 94-95.)

${ }^{3}$ LIERMANN, Richter, Schreiber, Advokaten 37-41.
} 
az egyre bonyolultabbá váló perjogot már nem tudta bárki átlátni, rájuk is ugyanazok a normák vonatkoztak, mint azokra, akik csak alkalmilag foglalkoztak perbeli képviselettel. Varga Endrével szemben Bónis ezt úgy fogalmazza meg, hogy ekkor még nem lehet ügyvédségről mint ügyvédi osztályról beszélni. ${ }^{4}$ A jogszabályok oldaláról vizsgálva ez azt jelenti, hogy egységes követelményrendszer velük kapcsolatban csak az 1694-es szabályzattal jött létre. Hazánkban ez foglalta össze első alkalommal az ügyvédekre vonatkozó elvárásokat, és előírta a kötelező ügyvédi esküt is, ezzel formálisan végképp elválasztva egymástól az ügyvédeket és azokat, akik az esküről szóló levél híján nem képviselhették megbízójukat a perben. A szokásjog megerősítette e szabályt, majd 1723-ban törvényben is rögzítették, hogy az eskü letétele nélkül az ország bíróságai előtt nem lehet képviselőként eljárni. Ez azonban még csak egyfajta erkölcsi szűrőként működött az ügyvédi „pályára” lépők részére: a szabályzatban foglaltaknak való megfelelést nem vizsgálták, ahogyan azt sem, vajon az ügyvéd jogi tudása, szakértelme elegendő-e. Először Mária Terézia idején (1769) tették kötelezővé az ügyvédi vizsgát a múködés előfeltételeként, majd 1804-től egy újabb rendelet ezt jogi tanulmányok elvégzéséhez és 2 év gyakorlati idő kimutatásához kötötte. A keretek tehát immár egyre pontosabban rögzültek, a kérdés pedig az volt, vajon elegendő-e mindez ahhoz, hogy az ügyvédség mint valóban ,tiszteletreméltó testület” jelenjen meg a jogkeresők szemében és az ország közéletében. A kifejezésnek mindkét tagja fontos: tiszteletre (és bizalomra) méltóvá válni, illetve testületté válni. Az ügyvédség - és ezen belül a most vizsgálandó budapesti ügyvédség - 19. századi története azt mutatja, hogy a kettő egymással szorosan összefüggött. Bónis is épp azt tartotta jelentős különbségnek a nyugat-európai ügyvédséggel való összehasonlításban, hogy a jogászság testületi szervezete és ennek a hivatási morálja, ami létezett pl. Angliában vagy Franciaországban, évszázadokon keresztül hiányzott a középkori Magyarországon. ${ }^{5}$

\section{Első kíséretek az ügyvédek összefogására}

A 19. században azonban már a hazai ügyvédek maguk is felhívták a figyelmet arra, hogy leginkább összefogással tehetnének annak érdekében, hogy a róluk keletkezett képet újrafessék, illetve hogy az ügyvédséget mind szellemi mind erkölcsi értelemben emelni tudják, továbbá valamiféle változást érhessenek el az együttes fellépés által. A reformkorban pedig még erôteljesebbé vált az igény a közösséggé szerveződésre, az önálló szervezeti keretek megteremtésére. Nem volt teljesen elôzmények nélküli az ügyvédek közti kooperáció, hiszen a Mária Terézৃa rendeletében foglaltakkal szembeni tiltakozásul már írtak a magyar kúriánál múködő ügyvédek egy közös feliratot, amelyet a királyi táblához címeztek, de azzal, hogy juttassák el a királynőhöz. ${ }^{6}$

1827-ben az országgyúlés újraélesztette a több jogterületre kiterjedő, 1790/91-ben elhatározott kodifikációt, s a törvénykezési szervezeten belül tüzetesebben szándékozott foglalkozni az ügyvédi állapotok rendezésével is. ${ }^{7}$ Az eddigi rendtartások mindegyike rendeletként látott napvilágot, ezért a törvénybe foglalás komoly előrelépést jelentett volna a szabályozásban. Az

\footnotetext{
${ }^{4}$ BÓNIS, A jogtudó értelmiség a Mohács előtti Magyarországon 11-12., VARGA, A hivatásos ügyvédi osztály kialakulása 625-642.

${ }^{5}$ BÓNIS, A jogtudó értelmiség a Mohács előtti Magyarországon 12.

${ }^{6}$ KUN, A magyar ügyvédség története 207-213., FÖLDVÁRI, A magyar ügyvédség és a magyar közélet 25-34. A rendelet következtében elvégzett összeírás szerint 39 ügyvéd múködött a királyi kúria mellett (az elvárt, szükséges 50-hez képest). Kun, A magyar ügyvédség története 206.
}

7 1827:VIII. tc. 
országos bizottság azonban még mindig a régi „nyomdokokon haladt”, az ügyvédek által megvalósítható jogsértéseket, a jogsértő ügyvédek elmarasztalását állítva a középpontba. ${ }^{8}$ A pesti ügyvédség színe-java már ekkor fellépett ezzel szemben, mivel méltánytalannak érezték ezt a beállítást. Ismét emlékiratot szerkesztettek, amelyben visszautasították, hogy a közvélemény tájékozatlanságából fakadó általánosításokat és az előítéleteket a törvényhozás a szabályozás kiinduló pontjaként fogadja el. Ahogyan Sárkány Jórsef fogalmazott, a pesti ügyvédség ezzel „a felébredt önérzetnek olly nemes és meleg kifejezést adott, melly már akkor öntudatos eréllyel hangsúlyožta a testületi szellem önbecsölését és bizalmat teremtö erkölcsi hatalmát”."

Közös, több ügyvéd által aláírt előterjesztésekkel a következő évtizedekben is lehet találkozni. A magyar ügyvédi kar 1896-os történeti kiállításának katalógusában található pl. testületi folyamodvány 1832-ből és 1845-ből is (a fenti memorandumok azonban nem szerepeltek e kollekcióban).$^{10} \mathrm{Az}$ 1832. évi petitumot a Hétszemélyes Táblához intézték „Curialis Prokatori kar” aláírással, és törvénykezési, valamint ügykezelési kérdésekkel foglalkozott, továbbá kérték az ún. „Procuratorie” üresen álló termének heti 2-3 alkalommal való rendelkezésre bocsátását ülésezés, tanácskozás céljából. A későbbi, 1845-ből való tétel „budapesti ügyvédek testületi folyamodványa” megnevezéssel került be a gyüjteménybe. A leírás szerint 46 ügyvéd aláírását tartalmazta ez a kérvény, amelyet a személynökhöz intéztek négy témakörben: a teremhasználat kérdésköre mellett (a Curia akkori épületében levő ún. „régi ügyvédi termet” kívánták visszakérni, amely valószínúleg azonos a korábban már igényelt teremmel) a zugírászkodás ellen, továbbá ismét ügykezelési reformok, illetve az öltözet szabályozása iránt szólaltak fel. Az utóbbi arra irányult, hogy az ügyvédek számára írják elő a nemzeti díszöltöny hordását.

Az ügyvédség tekintélyének emelése, a magasztos célok megvalósítása érdekében társulat alapításának az ötlete is felmerült. Az első ilyen kísérletről 1832-ből van tudomásunk, amikor egy jogi szótár megalkotása érdekében kívánt együttműködni a pesti ügyvédség, ám ez a kísérlet ekkor még eredménytelen maradt. ${ }^{11}$ Nem egészen egy évtized múlva, 1841-ben újra nyilvános összejövetelt tartottak és huszonegy tagból álló választmányt is alakítottak Benyous`ły Péter elnöklete alatt. A céljuk egymás jobb megismerése, továbbá a visszaélések elleni közös fellépés volt, valamint szakmai önképzést is meg kívántak valósítani azáltal, hogy majdani gyúléseiken nehezen eldönthető jogi kérdéseket vitatnak meg. ${ }^{12} \mathrm{E}$ testület későbbi működéséről sajnos nemigen lelhető fel anyag, illetve a jelen információk alapján nem állapítható meg pontosan, hogy mindazok az utalások, amelyeket a pesti ügyvédséggel kapcsolatban ezt követően találni (pl. az 1845-ből származó fent említett folyamodvány) vajon mennyiben kötődnek ehhez a szerveződéshez. Annyi bizonyos, hogy a pesti ügyvédi kar, amely ekkor még „,társulaton kivüli állapotban” volt, többször is összegyúlt a 40es évek végén és közösen is dolgozott egy olyan ügyvédi rendtartás tervezetén, amelyet az 1847-48-

\footnotetext{
${ }^{8}$ Egy későbbi ezzel ellentétes vélemény viszont épp azt mondja, hogy a törvények szigora fejlett etikai érzékre vallott, és éppen hogy emelte a becsületes munkát végző ügyvédek tekintélyét. MARKOS, Ügyvédi tisztesség és kari tekintély 134-135.

${ }^{9}$ A Budapesti Ügyvédi Kamara Közgyúlésének jegyzőkönyvei, 1875. 02. 20.

${ }^{10}$ Sík, A magyar ügyvédi kar történeti kiállításának katalogusa 18-19. (173. és 177. sorszám alatti tételek). Magáról a kiállításról később még lesz szó.

${ }^{11}$ Könnyen lehet, hogy ezek már a Törvénytudományi műszótár elkészítésének első lépései voltak, hiszen annak előmunkálatai 1831-ig vezetnek vissza. Törvénytudományi műszótár, III-IV.

12 Palugyay, Ügyvédek 67.
} 
as országgyúlés elé szerettek volna terjeszteni. ${ }^{13} \mathrm{Az}$ együttes törekvések mellett továbbá egyéni munkák is elkészültek. 1841-ben ifj. Palugyay Imre „Ügyvédek, korszerü tervezet ezelknek ügyében” címmel elsőként tette közzé az ügyvédi reformra vonatkozó elemzését, és ugyanebben az évben három ügyvéd (Német György, Ócskay Ignácz és Justh Ferenc) is előterjesztett bizonyos reformjavaslatokat (a források hiányossága miatt egyelöre sajnos nem állapítható meg, kihez és milyen tartalommal). ${ }^{14}$ 1848-ban jelent meg Tóth Lórinc „Ügyvédi állapotok. Röpirat ügyvédi érdekben” címú értekezése, majd szintén még ebben az évben Kaill Sándor „Ügyvédreform” címû brosúrája. ${ }^{15}$ Kaill mûve ráadásul egészen szoros kapcsolatot mutat a pesti ügyvédség készülő tervezetével, tudniillik az ügyvédválasztmány eredetileg az ő javaslatából indult ki, ám azon olyan lényegi változtatásokat tettek, amelyekkel a szerző nem tudott egyetérteni, ezért publikálta saját eredeti munkáját Deák Ferencigazságügyi miniszerhez címezve. ${ }^{16}$ A sors fintora, hogy az ő írása így fennmaradt, míg a pesti ügyvédség munkálata jelen ismereteink szerint nem.

\section{A Budapesti Ügyvédegylet megalakulása és a müködés kezdetei}

A szabadságharc eseményei meggátolták a kodifikációt, a neoabszolutizmusban pedig az oktrojált ügyvédi rendtartás autonómiával nem bíró ügyvédi választmányokat állított fel. Bár az Októberi Diplomát követően visszaállt az 1848 előtti magyar igazságszolgáltatási szervezet, és megcsillant a remény, hogy ügyvédi társulatok alapítására sor kerülhet, a provizórium idején, 1861-65 között ismét szóba sem kerülhetett, hogy bármilyen alulról induló magyar kezdeményezés szárba szökkenjen. Csak az 1860-as évek második felétől indulhatott meg az önszerveződés, és jöhettek létre az ügyvédegyletek, amelyek céljai a tudományos művelődés, a testületi szellem felébresztése, az ügyvédeket megillető erkölcsi hitel és tekintély fenntartása, törvényjavaslatok előkészítése és ezáltal a hazai jogélet fejlesztése, valamint özvegyeik, árváik segélyezése voltak. ${ }^{17}$

Mind közül ekkor is élen jártak a budapesti ügyvédek: „,...) a fôvárosi ügyvédi kar volt az̧, melly a legujabb idökben is minden módot és alkalmat megragadott a testületi szellem ébresztésére, nemesbitésére, s az. erkölcsi solidaritás eszményének érvényesitésére. A mit évtizedek hosszú sora nem tudott megérlelni, a mit nem lehetett még az idöben a törvényhozás terén diadalra juttatni, megkisérlette az̦ társulati téren megkeözelíteni”. ${ }^{18} \mathrm{~A}$ budapesti ügyvédegylet létrehozását Sárkány Jórsef már 1865. november 4-én egy ügyvédösszejövetel alkalmával indítványozta, ötlete pedig nyomban teljes elismerésre és helyeslésre talált kartársai részéről. ${ }^{19}$

\footnotetext{
${ }^{13}$ Életképek 1847/20. 641., KAILL, Ügyvédreform 6., TóTH, Ügyvédi állapotok 52.

${ }^{14}$ Sík, A magyar ügyvédi kar történeti kiállításának katalogusa 19. (175. tétel).

${ }^{15}$ KORSÓSNÉ, Az ügyvédi kamarák megszületése 17-30.

16 TÓTH, Ügyvédi állapotok 52., KAILL, Ügyvédreform, 6., 1848 nyarán Deák több jogterület kodifikációját is próbálta megkezdeni, és a perrend kapcsán az ügyvédségre is sort akartak keríteni. KORSÓSNÉ, Az ügyvédi kamarák megszületése 23.

${ }^{17}$ KORSÓSNÉ, Az ügyvédi kamarák megszületése 31-37., 95., KUN, A magyar ügyvédség története 303-304.

18 Sárkány József ünnepi beszéde 1875. 02. 20.

19 A tanácskozás célja eredetileg az volt, hogy Thanhoffer Pál bíró megkeresésére az igazságszolgáltatás helyzetének javításáról alakítsanak ki véleményt és adjanak neki tanácsot az ügyvédek. KuN, A magyar ügyvédség története 302303., KorSÓSNÉ, Az ügyvédi kamarák megszületése 95. A kassaiak sem maradtak el sokkal, 1865. 12. 03-án már ott is „elöleges értekęletet” tartottak és választmányt küldtek ki az alapszabály előkészítésére, de aztán 1866 őszéig húzódott ennek elkészülte. Az alakulás náluk is 1867 őszére tolódott. Törvényszéki Csarnok 1866/76. 308., 1867/72. 300.
} 
Az alakulás azonban mégsem ment olyan egyszerúen, mint ahogyan az első látszatra tűnt. Noha egy bizottság már hamarosan kidolgozta az alapszabály-tervezetet, az összehívott gyúlésen azt nem támogatta mindenki egyöntetűen, néhányan ahhoz ragaszkodtak, hogy zártkörű ügyvédi egylet legyen, mások viszont országos jogtudományi egyletet szerettek volna létrehozni. Így újabb tárgyalásokra került sor, míg megállapodtak és elfogadták a „Budapesti ügyvéd egylet” nevet, továbbá annak alapszabályait. ${ }^{20} \mathrm{~A}$ több lapban és többször is közreadott 1866. április 26-án kelt meghívóban - amely május 30. délután 5 órára szólt, az ún. 40-es bizottság által „véglegesen” megállapított alapszabály-tervezet megvitatására - a budapestieken kívül a vidéki ügyvédeket is invitálták. ${ }^{21} \mathrm{Az}$ egyleti alapszabályok (3-4. §) ugyanis különbséget tettek rendes és tiszteletbeli tagok között, az előbbieket pedig alapítókra, rendes beltagokra és kültagokra osztották, aszerint, hogy Budapest területén belül vagy kívül laktak. Rendes alapító tag az lehetett, aki legalább $200 \mathrm{Ft}$ alapítványi tôkét fizetett be az egylet javára. Az alapító és a tiszteletbeli tagok tagsága élethosszig illetve az egylet fennállása idejéig tartott, míg a többi tag esetében öt évente meg kellett újítani az „alaírást”, azaz a tagságot (6. §). A tagságról szólva említést érdemel, hogy annak alapja nem az volt, hogy valaki folytat-e ügyvédi gyakorlatot, hanem hogy rendelkezik-e ügyvédi oklevéllel. Így olyan az igazságszolgáltatásban vagy a közigazgatásban múködő neves jogászok is tagjai lehettek (és lettek is) az ügyvédegyletnek, akik nem az ügyvédi pályán dolgoztak. ${ }^{22}$

Az egylet megalakulását be kellett jelenteni a belügyminiszternek, s az általa jóváhagyott alapszabályokat 1867-ben a hírlapokban is közzétették. ${ }^{23}$ Horváth Károly ideiglenes egyleti elnök 1867. augusztus 2-án intézett nyilvános felhívást az ügyvédi karhoz, amelyben örömét fejezte ki, miszerint végre eljött az idő, „hogy karunk érdekeinek emelésére az egyesek nemes szándéka és tettereje egyesüijöo”. Szólt az egylet céljairól (az ügyvédi kar társadalmi érdekein kívül a tudomány előmozdítása, a tagok és családtagjaik segélyezése) ${ }^{24}$, és arról, hogy ezeket annál könnyebben el

\footnotetext{
${ }^{20}$ KUN, A magyar ügyvédség története 303. A Budapesti ügyvédegylet alakulási évének - valószínűleg az első erre irányuló javaslat igenlésétől számítva - 1865-öt szokták tekinteni, de 1866-ban fogadták el az alapszabályokat, amelyek 17. \-a szerint az egyleti pecséten a „Budapesti ügyvédi egylet 1866.” körirat szerepelt, maga az alakuló közgyúlés pedig a belügyminiszteri jóváhagyást követően 1867-ben volt. A budapesti ügyvédi egyletnek a m. kir. miniszterium által jóváhagyott alapszabályai, Jogtudományi Közlöny 1867/33. 185-188. A nevet nem következetesen használták, pl. az alakuló közgyúlésre szóló felhívásban a „pest-budai ügyvédi egylet” elnevezés szerepelt. Jogtudományi Közlöny 1867/36. 216.

21 Különfélék. Simon Florent bizottmányi elnök aláírásával. Jogtudományi Közlöny 1866/20. 319. Értesítés. Törvényszéki Csarnok 1866/35. 140., 1868/41. 164.

${ }^{22} \mathrm{Pl}$. bírák is tagok lettek, sőt Horvát Boldiæsár igazságügyi miniszter is jelentkezett alapító tagnak. Tárcza. A „Budapesti ügyvédi egylet” f. hó 5-ki közgyülése. Jogtudományi Közlöny 1867/45. 283. Előfordult azonban, hogy ez ellentéteket is szült az egyleten belül, mint azt egy 1869-ből „,egy egyleti ügyvéd” aláírással megjelent vélemény is tükrözi. Röviden arról volt szó, hogy az egylet közgyúlésében leszavaztak egy indítványt, amely egy elhunyt kartársról való jegyzőkönyvi megemlékezésre vonatkozott. A szerző úgy vélte, az ellenvéleménynek hangot adó tag azért nem állt a javaslat mellé, mert nem gyakorló ügyvéd, hanem hivatalnokként dolgozik, így „reá nézve egészen kétes becsü kincsnek tekinti az ügyvédi testület erkölcsi tekintélyét, mert ó egy más testületnek. lévén tagja, — föleg ennek, tekintélyét óbajtja emelni." A b.-pesti ügyvéd-egylet f. évi r. közgyúléséből. Törvényszéki Csarnok 1869/18. 69-70.

${ }^{23}$ Jogtudományi Közlöny 1867/33. 185-188., 192., Törvényszéki Csarnok 1867/63. 254., 257-258.

${ }^{24}$ Az alapszabály pontosan a következőképpen határozta meg az ügyvédegylet céljait (1.()): „Az ügyvédi testületet megillető erkölcsi bitel és tekintély fenntartása, — tudományos képzettségének elómozdítása, — a jog-és államtani ismeretek. fejlesztése és terjesztése; különösen a hazai törvénykezés terén felmerült jogkérdések fejtegetése, a törvénykezési biányok feletti véleményezés, a czélszerüeknek mutatkozó javaslatok törvényszabta módokon és helyeken elöterjesztése és ekkép egyleti közremüködés a hazai jogélet egységes fejlesztése és javitására; végre a betegség vagy egyéb szerencsétlenség által sújtott és megszorult egyleti tagoknak, ezek özvegyeinek és árváinak segélyezése; sqóval: az ügyvédi testület társadalmi összes érdekeinek elómozdítása.”
} 
tudják majd érni, minél több tagot számlál az egylet, így felhívta „Magyarorşág összes okleveles ügyvédeit, hogy a budapesti ügyvédi egyletbe, mint tagok belépni sziveskedjenek.".

Magát az alakuló közgyúlést 1867. szeptember 28-ra tűzték ki, a helyszín a „városi tárgyalási terem" volt. A hirdetményben az is szerepelt, hogy akkor fogják megalakultnak nyilvánítani az egyletet, ha a résztvevők száma a már írásban jelentkezetteken kívül a 100 fôt eléri. ${ }^{26}$ Az első „felvonás” eredményes volt, mert az alapszabályt aláírásukkal már ekkor sokkal többen fogadták el magukra kötelezőnek, mint azt az alakuláshoz elvárták, ám az alakulási közgyúlés nem tudta elvégezni a munkáját az első alkalommal, így azt október 19-én folytatták a „városi törvényszéki tárgyalási nagyteremben (Piaristák) '27 , amikorra a már aláírt és még aláírni kívánó tagokat ismét felhívták megjelenésre, hogy az alakulást befejezhessék és az egyleti tisztségviselőket és választmányi tagokat is megválaszthassák. ${ }^{28} \mathrm{Ez}$ azonban nem történt meg 19-én. Az ideiglenes elnök hosszú ünnepi beszédet tartott, amelyet a Jogtudományi Közlöny teljes egészében közölt, azzal a jegyzettel, hogy a soron következő lapszámban az ülés jegyzőkönyvét is közreadják. ${ }^{29}$ A következő szám viszont csak egy tömör, pár soros összefoglalót tett közzé a gyűlésről, amelynek végén a következőt kissé pikírt megjegyzés olvasható: „F. hó 26-án fognak a válasz̨tmányi tagok s egyleti tisztviselók választatni. Reméljük, hogy az egylet ekekor haladéktalanul szellemi müködését is megkędendi, mert eddig ugyan lassan baladtunk.. 'º Végül a folytatólag tartott közgyúlés 1867. november 5-én eredménnyel járt, az alakulás befejeződött. ${ }^{31}$

Az első rendes közgyúlést 1868. január 26-án tartották, tudniillik a rendes közgyúlés megtartására minden év január harmadik vasárnapját írta elő az alapszabály (19. §). Ekkorra 284 tagja volt az egyletnek. ${ }^{32}$ Az első, 1868. évben három közgyúlésre is sor került.. ${ }^{33}$ (Rendkívüli közgyűlést az elnöknek akkor kellett összehívnia, ha a választmány vagy legalább 20 rendes tag az indokok felsorolásával ezt írásban kérte.)

Az ügyvédegylet megalakulása és megítélése körül még ez idő tájt is akadtak nézeteltérések. A Jogtudományi Közlöny 1868. évi első számában számolt be arról, hogy milyen tartalmú támadás érte a Magyar Újság hasábjain az egyletet, és egyetértőleg közölték a titkár válaszát is azzal a megjegyzéssel, hogy úgy érzik, az egylet létrejötte inkább üdvözlendő, és semmi szükség a gáncsoskodásra, ami csak rontja az ügyvédi kar hírnevét. (A támadó, bizonyos $V$. G. főképp azt kifogásolta, hogy az ügyvédegylet szellemisége nem eléggé szabadelvű, nem találta kellően magasztosnak az egyleti célokat, továbbá a felvételrôl vagy fel nem vételről szóló döntéshozatalt is kifogásolta. A cikk az sejteti, hogy esetleg egy fel nem vett, sértődött jogász állhat a monogram

\footnotetext{
${ }^{25}$ Különfélék. Jogtudományi Közlöny 1867/33. 192.

${ }^{26}$ Felhívás a pest-budai ügyvédi egylet alakulási közgyúlésére. Jogtudományi Közlöny 1867/36. 216., Törvényszéki Csarnok 1867/69. 284. Az azonos című, tartalmú és szinte azonos szövegezésű felhívásokban egy sajtóhiba miatt lényeges eltérés mutatkozott. Az ülés napjaként a Jogtudományi Közlönyben 09. 28., míg a Törvényszéki Csarnokban - tévesen - 09. 26. szerepelt. A tévedést egy későbbi lapszámban feltűnően szedve korrigálták. Törvényszéki Csarnok 1867/71. 296.

${ }^{27}$ Valószínúleg ugyanezt jelölte az előző felhívás „városi tárgyalási terme” is.

${ }^{28}$ Felhivás a pest-budai ügyvéd urakhoz. Jogtudományi Közlöny 1867/41. 256., Törvényszéki Csarnok 1867/79. 330.

${ }^{29}$ Jogtudományi Közlöny 1867/42. 257-260.

30 Különfélék. Jogtudományi Közlöny 1867/43. 272.

${ }^{31}$ Maga az elnök is megjegyezte: „hogy az idô elóhaladt, s egyletünk késón ébredt életre; azért gyors és kettő ztetett munkásságra van szülkség.” Tárcza. A „Budapesti ügyvédi egylet” f. hó 5-ki közgyülése. Jogtudományi Közlöny 1867/45. $282-283$.

32 A budapesti ügyvédi egylet által Pesten 1868. évi január hó 26-án tartott közgyúlés jegyzökönyve. Jogtudományi Közlöny 1868/7., 49.

${ }^{33}$ Elnöki jelentés a budapesti ügyvédi egyletnek 1868-ik évi működéséről. Jogtudományi Közlöny 1869/6. 41.
} 
mögött.) $)^{34}$ Az első közgyűlés is hangos volt azoktól az esetektől és az ezek által kiváltott vitáktól, amelyek középpontjában az alapszabály ama rendelkezésének érvényesítése állt, hogy a tagfelvételről a választmány dönt titkos szavazással, és a döntést nem kell indokolni, a visszautasítással szemben pedig a közgyűléshez lehet folyamodni. Volt, aki visszavonta kérelmét, arra hivatkozva, hogy nem is kíván olyan társulat tagjává válni, ahová csak fellebbezéssel tud bejutni, más becsületbíróság kiküldését szerette volna ügyében. Hosszas vitatkozás után végül elvetették az alapszabályok módosítását, a metódus az előbb ismertetett maradt. ${ }^{35}$

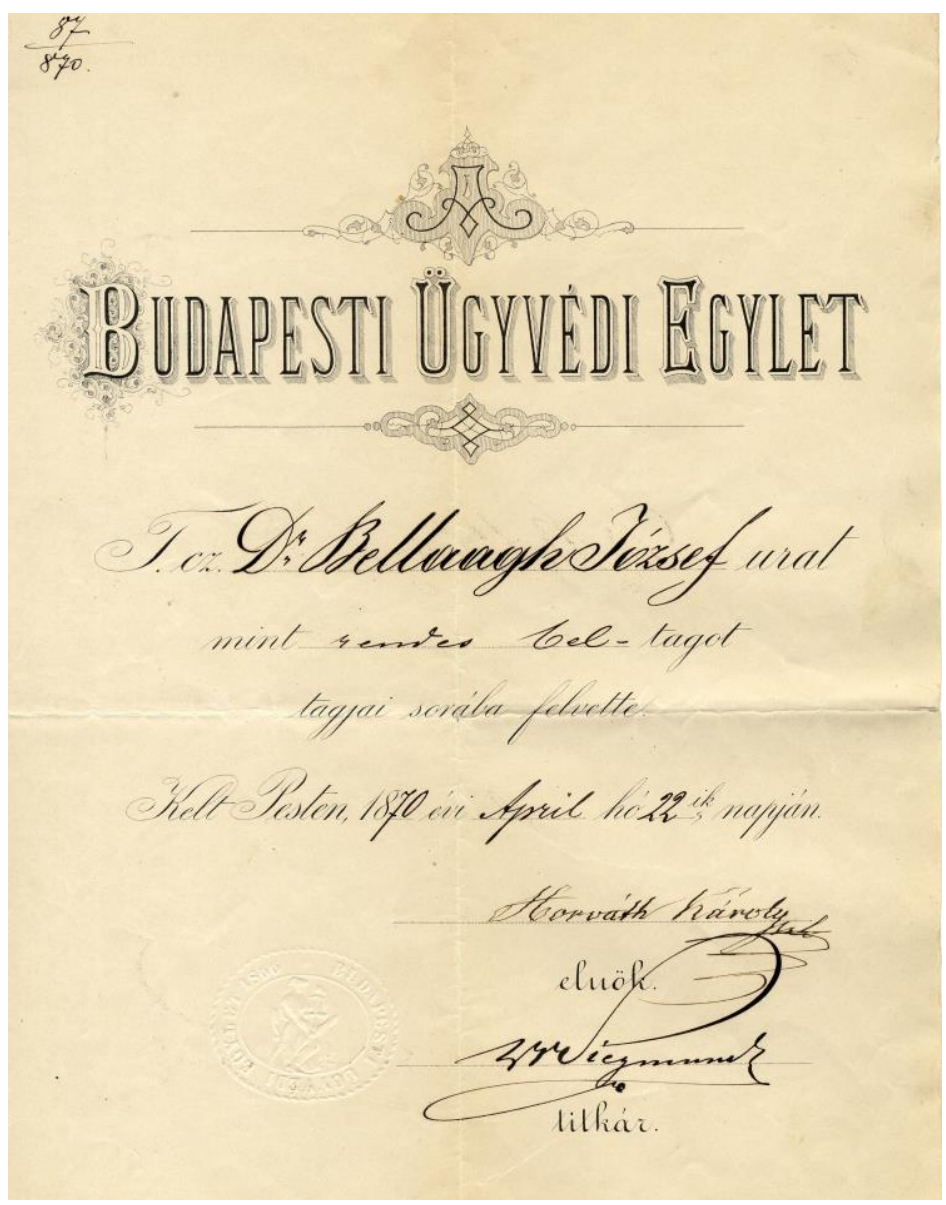

Az egylet tagjaiból igazgató választmányt alakított, amely harminc választmányi tagból, valamint a szintén választott hét egyleti tisztviselőből állt (elnök, alelnök, titkár, ügyész, pénztárnok, ellenőr, könyv- és irattárnok). Első alkalommal az alakuló ülésen, később a rendes éves üléseken kellett a választásokat lefolytatni, a mandátum 1-1 évre szólt, a tisztségviselők a közgyúlés által megállapított fizetésben részesültek (15-16. S). Az első elnök Horváth Károly, az első alelnök a kezdeményező Sárkány József lett, titkár Matolay Elek, pénztárnok Polgár Mibály, ellenőr Funták Sándor, könyv- és irattárnok Bogdány Lajos, ügyész Gál Ernö. ${ }^{36}$ (Később a jegyzőkönyveket, adatokat összefog-laló módon az egyleti évkönyvek tartalmazták, az elsőt az 1869-70-es évekről adták ki). ${ }^{37}$

1. kép: A Budapesti Ügyvédi Egyletbe rendes tagként történt felvételrôl kiállított okirat Bellaagh József részére ${ }^{38}$

Az 1867. év végén már előkészületeket tettek a szakosztályok megalakítására, ${ }^{39}$ amelyek közül némelyik még decemberben, a többi a következő januárban létrejött és még 1868-ban

\footnotetext{
34 Budapesti ügyvédegylet. Jogtudományi Közlöny 1868/1. 6-7.

35 Különfélék. (A budapesti ügyvédegylet) Jogtudományi Közlöny 1868/5. 40.

${ }^{36}$ A „Budapesti ügyvédi egylet” f. hó 5-ki közgyülése. Jogtudományi Közlöny 1867/45. 282.

${ }^{37}$ SIEGMUND, A Budapesti ügyvéd-egylet évkönyve 1869/70

${ }^{38}$ Magyar Nemzeti Digitális Archívum, https://mandadb.hu/tetel/388617/Bellaagh_Jozsef_a_Budapesti

_Ugyvedi_Egylet_rendes_tagja_1870, felhasználási licenc: https://creativecommons.org/licenses/by-nc-nd/4.0

(2020. 07. 02.)

${ }^{39}$ Különfélék. (A Budapesti ügyvédi egylet) Jogtudományi Közlöny 1867/52. 352.
} 
megkezdték múködésüket is. ${ }^{40}$ Elsősorban a négy szakosztály és a havonta tartandó rendes ülések szolgáltak a tudományos múködés kifejtésére. ${ }^{41}$ Az egylet könyvtárat hozott létre, ${ }^{42}$ helyiségekkel rendelkezett (ezek közül egyik a könyváré, egyúttal olvasóterem is) és személyzetet is tartott. ${ }^{43} \mathrm{Az}$ alapszabály az igazgató választmányra bízta, hogy „az egyleti múködéseknek megfelelő alkalmas sqállásról” gondoskodjék (12.』). Az első rendes közgyúlésen a titkár arról számolt be, hogy még nem sikerült helyiséget szerezni, de Szent György napjától már biztosítva lesz, majd egy későbbi rendes ülésen a nyárra ígérik a beköltözést. ${ }^{44}$ Az egylet helyiségeit a Váci utcában az ún. Szentkirályi-féle házban rendezték be és 1868 szeptemberében már itt tartottak ülést. ${ }^{45}$

Az első közgyúlés azt is elfogadta, hogy az egylet hivatalos lapja a Jogtudományi Közlöny lesz, így ha a soron következő számtól a beharangozással ellentétben még nem is, de 1868. február 16-tól már mint „A budapesti ügyvédi egylet közlönye” jelent meg, amelyben a közgyúlések hiteles jegyzőkönyveit is közzétették. ${ }^{46}$

Az alapszabályok 12. \-a alapján még az 1867 novemberi alakuló közgyúlésen megalkotott házi szabályaikból kiolvasható továbbá az egyleti múködés néhány fő vonása. ${ }^{47}$ Eszerint az egylet helyiségei reggel 9-től este 10 óráig, és amennyiben valaki még jelen volt, legfeljebb éjfélig tartottak nyitva, azokat a tagok és a vendégeik általában szabadon használhatták, fôként „társalgás és olvasásra”, a játék minden formáját azonban az egylet falai közül kizárták. A rendes ülési termet és a választmányi ülés termét csak akkor vehették igénybe a tagok, amikor ezekben ülést nem tartottak. A rendes ülés nem azonos a fentebb tárgyalt közgyúléssel, amelyre a helyszínt esetről esetre a választmány határozta meg. (Egy közös volt mégis ezekben az ülésekben: mindegyikben tiltották a házi szabályok a dohányzást.) Az egyleti könyvtárat és a hírlapokat a tagok és vendégek helyben szabadon használhatták, és kölcsönözni is lehetett (egy személynek egyszerre csak egy munkát, legfeljebb egy hétre). Az egylet által alkalmazott szolgákat azonban senki nem vehette igénybe „a belyiségeken kivül teljesitendő szolgálatra”. A közvetlen társalgáson kívül a tagok az e célból a

\footnotetext{
${ }^{40}$ Különfélék. (A budapesti ügyvédegylet) Jogtudományi Közlöny 1868/5. 40., Különfélék. (A budapesti ügyvédegylet) Jogtudományi Közlöny 1868/7. 56. Elnöki beszéd, a buda-pesti ügyvédi egyletnek 1869. jan. 31-én tartott első rendes közgyúlésén, SIEGMUND, A Budapesti ügyvéd-egylet évkönyve 1869/70 9., KORSÓSNÉ, Az ügyvédi kamarák megszületése 55 .

${ }^{41}$ Már kb. egy év elteltével kritika is érte az egyleti apparátus nehézkességét, hogy a szabályok szerinti működés sokszor túlságosan és feleslegesen elnyújtja a tárgyalási folyamatot, esetenként akadályozza a gördülékeny szakmai munkát. Budapesti ügyvéd egylet. Törvényszéki Csarnok 1869/7. 28.

42 TAKÁCS, Alternatív könyvtárak 14-15.

${ }^{43}$ Az első évben valószínűleg még csak 1 főt alkalmaztak, legalábbis a közgyűlésben elfogadott költségelőirányzat szerint. Különfélék. (A budapesti ügyvédegylet) Jogtudományi Közlöny 1868/5. 40.

${ }^{4}$ Különfélék. (A budapesti ügyvédegylet) Jogtudományi Közlöny 1868/5. 40., Jogtudományi Közlöny 1868/21. 161.

${ }^{45}$ Jogtudományi Közlöny 1868/39. 308., 1868/40. 314. Ugyanekkortól, 1868. szeptember végétől költözött ebbe az épületbe, a 3. emeletre a Jogtudományi Közlöny szerkesztői irodája is, amely előtte a Deák utca 14. alatt múködött. Jogtudományi Közlöny 1868/38. 297., Jogtudományi Közlöny 1868/39. 301. A Szentkirályi-ház a később „Thonetházként” nevezetessé lett épület szomszédságában található saroképület volt. Fővárosi Lapok 1890/263. 1933.

${ }^{46}$ Különfélék. (A budapesti ügyvédegylet) Jogtudományi Közlöny 1868/5. 40., 1868/6. 41., 1868/7. 49. 1969-ben felvetődött, hogy ez változzon meg és a Törvényszéki Csarnok legyen az új hivatalos egyleti közlöny, tekintettel arra, hogy „az ügyvédegyletek függetlenségének jobban megfelel, ha független, nem a kormánytól függő szakilap által képviseltetnek”, de a javaslatot elvetették. Törvényszéki Csarnok 1869/11. 44. (A Törvényszéki Csarnokot később a debreceni, majd az eperjesi ügyvédegylet választotta hivatalos lapjául és a Jogtudományi Közlöny a budapestiek mellett később további egyletek - nagyváradi, kassai, kolozsvári stb.- hivatalos lapjává is vált. A budapesti egylet 1872-ig szerepelt a Jogtudományi Közlöny címlapján, egyéb ügyvédegyletek pedig 1876. év végéig.)

47 Tárcza. A „Budapesti ügyvédi egylet” f. hó 5-ki közgyülése. Jogtudományi Közlöny 1867/45. 283., SIEGMUND, A Budapesti ügyvéd-egylet évkönyve 1869/70 230-231.
} 
helyiségekbe kitett fekete táblán rövid üzeneteket, értesítéseket hagyhattak egymásnak, „melyek azonban 48 óra multán letöröltetnek”. Hirdetéseket is ki lehetett függeszteni ugyanitt, de ezekre előbb meg kellett szerezni a titkár ellenjegyzését. Hogy elkerüljék a különböző, az egylethez beérkezett aláírási ívek ,alkalmatlan kínálását”, minden ilyesmit szintén e tábla közelében egy asztalon helyeztek el. Ugyanitt találták a tagok a panaszkönyvet, amelybe panaszaikat és kívánságaikat jegyezhették be (,mindennemü panaszok, akár a belyiségek rendét, akár a szolgák eljárását tárgyazzák, akár pedig a helyiségek czélsz̧erübb kezelését tárgyazó kivánságok”").

\section{Az ügyvédegylet szerepe az ügyvédi rendtartás és a Budapesti Ügyvédi Kamara létrejöttében}

Az ügyvédegyletek mérföldkövet jelentettek az ügyvédi kar hazai szerveződéstörténetében, azonban a budapesti ügyvédségnek a többinél is komolyabb szerep jutott, különösen a jogszolgáltatással kapcsolatos reformok ügyében. Ahogy Kun Lás₹̨ó írja a századvégen: „,z̧ellemi tevékenységét a kormány gyakran igénybe vevén [...] csakhamar oly eröt fejtett ki a jogtudomány s törvénykezés terén, hogy az igazságügyi kormányzásnál még nagyobb méltatásra talált”. 48

Az egylet IV. (bírói szervezeti, magánjogi, perrendtartási és jogtanulmányi) szakosztálya már részt vett az 1868-as polgári törvénykezési rendtartás javaslatának bírálatában, sôt, saját értékelésük szerint a polgári bíráskodás alapelveinek kidolgozásában is döntő szerepet vállalt. ${ }^{49}$ Ugyanez a szakosztály 1868-ban bizottmányt küldött ki az ügyvédi rendtartás alapelveinek kijelölésére, akár önálló javaslat szerkesztésére..$^{50}$ A Siegmund Vilmos vezetésével dolgozó bizottság az utóbbi utat választotta, 1869-re elkészült tervezetüket a szakosztály 10 ülésen keresztül kb. két hónapig tárgyalta, majd a rendes ülés elé terjesztette. 1870-ben a közgyúlés is elfogadta a „Törvényjavaslat az. 'ügyvédrendtartás' tárgyában. (Magyar- és Erdélyország számára.)” címú munkát, amelyet novemberben felterjesztettek az igazságügyi minisztériumhoz. Ez természetesen önmagában még nem jelentett volna semmi különöset, hiszen készültek már korábban is, pl. a reformkorban, olyan tervezetek, amelyek aztán semmiféle hatást nem gyakoroltak a törvényhozásra. Ez a munka azonban gerincét képezte az 1874. évi ügyvédi rendtartásnak, de legalábbis a törvény legelső, 1871-ben az igazságügyi miniszter által szakmai véleményezésre közzétett tervezetének.

A minisztériumban ugyanis az ügyvédi rendtartás ezzel párhuzamosan készülő javaslatát a beérkezett operátum alapján újból átvizsgálták és több helyen módosították, sőt egyes szakaszait (ezeket az 1871-es minisztériumi javaslat pontosan felsorolja) az ügyvédegyleti szövegezés precizitása, szabatosabb és teljesebb volta miatt abból szinte szóról szóra átvették. Elismerték, hogy az anyag azért is különös figyelmet érdemel, mivel a hazai ügyvédi karnak saját viszonyai rendezésére vonatkozó nézeteit tükrözi, így „a közvélemény legjogosabb nyilvánulásának tekinthetö". ${ }^{51}$ Hangsúlyozták annak fontosságát, hogy a rendtartás alapvető elveiben (egység, testületi vagy

\footnotetext{
48 KUN, A magyar ügyvédség története 304.

49 „kidolgozta a birói szervezési alapelveket”, Elnöki beszéd, a buda-pesti ügyvédi egyletnek 1869. jan. 31-én tartott első rendes közgyűlésén. SIEGMUND, A Budapesti ügyvéd-egylet évkönyve 1869/70 10.

${ }^{50}$ A Budapesti ügyvédegylet negyedik (bírói szervezeti, stb.) szakosztályának évi jelentése 1868. és 1869. évről. SIEGMUND, A Budapesti ügyvéd-egylet évkönyve 1869/70 127.

${ }^{51}$ Javaslat az ügyvédi rendtartás tárgyában (1871). Indokolás 47.
} 
kamarai elv, felelősség, fegyelmi hatáskör, képzettség, önállóság és függetlenség, szabad működés és szabad verseny, ellentételezés) az ügyvédség és a kodifikátorok kezdettől fogva egyetértettek. ${ }^{52}$

Az átdolgozásokat követően 1873-ban az országgyưlés elé kerülő törvényjavaslatot a budapesti ügyvédi kar némi elfogultsággal úgy értékelte, hogy az „egész̧ben és nagyjában (...) az egylet munkálatával megegyezilk”, továbbá: „A budapesti ügyvédi egylet munkálkodása alig találbatott bóditóbb elismerést, mint melyet az ügyvédi rendtartás nyújt, midön ennek indokolásában elismertetik, hogy az egylet által beterjesztett tervezet alapján a törvényjavaslat átdolgoztatott és az egylet munkálatának legtöbb rendelkezése szabatosabb és kimeritóbb szerkęete miatt egész̧ben elfogadtatott. ${ }^{53}$

Mindeme előzményeket ${ }^{54}$ követően született meg az 1874. évi XXXIV. törvénycikk, az első modern magyar ügyvédi rendtartás. A benne foglalt felhatalmazás alapján az igazságügyi miniszter 35.365/1874. december 28-án kiadott körrendeletével meghatározta a kamarák székhelyeit és beosztását, a következő évben pedig megalakult az ország 28 ügyvédi kamarája. ${ }^{55} \mathrm{Az}$ eredeti tervek, az 1871-es javaslat szerint csupán 15 kamara lett volna, tudniillik a külföldi minták vizsgálata alapján nagyobb létszámú ügyvédi kamarák létrehozása tűnt célszerűnek. Az alacsony kamarai taglétszámban rejlett ugyanis némi elfogultság pl. a testületen belüli bíráskodás szempontjából. ${ }^{56}$ Végül - nem szakítva magával az eredeti megfontolással - a törvény előírta, hogy egy kamara létrehozásához minimum 30 ügyvéd szükséges, de azt nem szabta meg, hogy összesen hány kamara lehet az országban.

A Budapesti Ügyvédi Kamara esetében ez a megszorítás mintegy felesleges volt. Az alakuló közgyűlésen ugyanis 430 fő ügyvéd vett részt. Hozzá kell tenni, hogy a miniszteri rendelet alapján ez nem csupán a fővárosi ügyvédséget jelentette, hanem a budain és a pestin kívül az Esztergomi, a Kalocsai valamint a Pestvidéki királyi Törvényszék területén múködő ügyvédek is ide tartoztak. Még akkor is érdemes ezt megjegyezni, ha tény, hogy a fővárosi ügyvédség már ekkor is jóval nagyobb létszámot tett ki, mint a vidéki. ${ }^{57} \mathrm{Az}$, hogy a kamara vidéki tagokkal fog megalakulni, már az előző év végétől kezdve élénken foglalkoztatta a budapesti ügyvédeket és okozott „mozgalmakat” az ügyvédségen belül. Különféle nézetek láttak arról napvilágot, hogy a kamarai tisztséget betöltők, valamint a választmányi tagok közül (az erre vonatkozó törvényi előírások figyelembe vételét követően is) mennyi vidéki és mennyi fővárosi ügyvéd legyen. ${ }^{58}$ Előzetes tárgyalásokat, értekezleteket tartottak az ügyvédek, és a kortársak beszámolói szerint igen heves érzelmeket váltottak ki a közelgő kamarai választások. Végül a hetekig tartó „pártcsatározásokat” követően úgy jutott nyugvópontra a vita, hogy a választás előkészítésére egy ún. „ajánló hetes

\footnotetext{
52 Apróbb vita abban kimutatható az egylet és a minisztérium között, hogy az alapelvek végső soron melyik szervtől származtak, mert mindegyik magának tulajdonította ezek kidolgozását. KORSÓsNÉ, Az ügyvédi kamarák megszületése 56.

53 A rendes ülés elintézett tárgyai. Észrevételek az "ügyvédrendtartási törvényjavaslatra". SIEGMUND, A Budapesti ügyvéd-egylet évkönyve 187161.

${ }^{54}$ Részletesebben lásd KORSÓSNÉ, Az ügyvédi kamarák megszületése 55-58.

${ }^{55}$ Hozzá kell tenni, hogy a minisztérium eredeti tervei szerint csak 24 kamara lett volna, ügyvédi kéréseknek engedve határozott meg végül a rendelet 27 kamarát, és csak 1875 őszén módosították a kamarák számát 28-ra (miközben a szombathelyi kamara az eredeti rendeletben foglaltakkal ellentétben még áprilisban önállóan megalakult). MÁTHÉ, A magyar burzsoá igazságszolgáltatási szervezet 404., Jogtudományi Közlöny 1875/1. 8., KORSÓSNÉ, Az ügyvédi kamarák megszületése 92-93.

${ }^{56}$ Javaslat az ügyvédi rendtartás tárgyában (1871). Indokolás 58-59.

${ }_{57}$ TÓTH, A budapesti ügyvédi kamara alakulásáról 8., Sőt, júniusban már meghaladta a kamarai tagok létszáma a 700 föt. Jogtudományi Közlöny 1875/26. 224.

58 TóTH, A budapesti ügyvédi kamara alakulásáról 7-8.
} 
bizottságot" hoztak létre. Ez a bizottság, úgy tűnik, be tudta tölteni a közvetítő szerepet a különféle nézetű tömörülések között és mindegyik irányzat véleményét figyelembe véve egy névsort állított össze a kamarai posztokra jelentkező és ajánlott személyekből. Ezt a listát - noha nem tették zárttá - a közóhaj összefoglalásának tekintették. Csak olyan személyeket vettek rá fel, akikről úgy vélték, hogy a közbizalom méltán tartja őket érdemesnek valamely kamarai tisztség betöltésére, és akik nem tartoznak egyik szélsőséges, önös érdekeket szem előtt tartó klikkhez sem. A kívánalom úgy szólt, hogy a kamarai választás során pártállástól függetlenül mindenki gondoljon a magasztos célra, a magyar ügyvédi kar reputációjának helyreállítására. ${ }^{59}$

Az alakuló ülést 1875. február 20-án tartották a pesti megyeháza üléstermében, amely alkalmas volt ekkora létszám befogadására. Az épület már korábban is szolgált a vármegyei közgyűlések tartásán kívül jeles célokat. ${ }^{60} \mathrm{~A}$ budapesti ügyvédségnek alkalmas saját épülete ekkor még nem is volt, az épp létrejövő kamarának pedig nyilvánvalóan semmilyen. Az elhelyezésről 1875 nyarától van adat, ugyanis a Jogtudományi Közlönyben is hírül adták, hogy a kamara június 15-tôl a belvárosi Zöldfa utca (ma Veres Pálné utca) 12/a alatti , saját helyiségeibe” költözött. ${ }^{61}$ Székházépítés céljaira a székesfőváros csak később, 1893-ban adományozta azt a Szemere utca és Szalay utca sarkán lévô telket, amelyen ma is áll a kamara épülete. ${ }^{62} \mathrm{Az}$ adomány előzményei 1892-re nyúlnak vissza, és a fővárosi közgyúlés ezzel a nagylelkű felajánlással egyúttal az ügyvédek által kifejtett pozitív ténykedést is elismerte. Az adományozást a belügyminiszter 1893. május 1-jén kelt 33921. (III. 5.) sz. rendeletével jóváhagyta, a szerződés a székesfóváros és a kamara között így júliusban létrejöhetett. A szerződés tartalmazta, hogy az e telken emelendő épületet ne használhassák idegen célokra, hanem kizárólag olyanokra, amelyek a kamarának akár mint hatóságnak, akár mint autonóm ügyvédi testületnek természetéből, rendeltetéséből, hatásköréből, vagy önmaga által hatáskörén belül, vagy törvényben kitűzött és kitűzendő feladataiból folynak. A tulajdonjogot hamarosan átjegyezték, a telket a kamara birtokba is vette és választmányt küldött ki az építkezés előkészítésére, azzal a céllal, hogy azt már 1894-ben megkezdjék. Az épület végül a Millennium évére, 1896-ra készült el, és rendkívüli közgyűlés keretében tartott ünnepséggel nyitották meg. ${ }^{63}$

Visszatérve a kamara megalakulására, a nyitó beszéd megtartására Sárkány Józsefet ${ }^{64}$, a Pesti királyi Törvényszék 1871-ben kinevezett elnökét kérték fel, hiszen a rendtartás azt írta elő (110.\$), hogy az alakulás végett az a törvényszéki elnök hívja össze a kamara kerületébe tartozó összes

\footnotetext{
${ }^{59}$ SIEGMUND, A budapesti ügyvédi kamara alakulása 1.

${ }^{60}$ Mindaddig például, amíg a Magyar Tudományos Akadémiának saját épülete és reprezentatív terme nem volt (1865), az Akadémia üléseit jobbára itt, a pesti Vármegyeháza dísztermében tartotta. Az MTA székháza, https://mta.hu/hatteranyagok/az-mta-szekhaza-105350 (2020. 07. 21.)

${ }^{61}$ Jogtudományi Közlöny 1875/25. 216., https://hungaricana.hu/hu/budapest-idogep/terkep/ (2020. 07. 21.)

${ }^{62}$ A döntés az 1893. február 22-én tartott fôvárosi közgyúlésen született. Ügyvédek Lapja 1894/13. 5.

${ }^{63}$ Jogtudományi Közlöny 1896/38. 304.

${ }^{64}$ Sárkány József (1828 - 1903) ügyvédi oklevelét 1847-ben szerezte. Az 1848-as pozsonyi országgyúlésen a pest megyei követek mellett múködött, Kossuth követi irodájának is a főnöke lett, majd Kossuth pénzügyminisztersége kezdetekor maga mellé vette elnöki fogalmazónak. A szabadságharcban hadbíró volt, de harcolt is, és őrnagyi címig vitte. Rövid külföldi tartózkodásból 1850-ben visszatérve ügyvédként működött, később Pest városa képviselőtestülete tagjává választotta. 1869-ben nevezték ki bírónak a királyi ítélőtáblához, emellett a pestkerületi esküdtszéki sajtóbíróság teendőivel megbízott táblai küldöttség elnök is volt. 1871-től a Pesti királyi Törvényszék, majd 1872-től 1875 októberéig volt a - miniszteri biztosként általa megszervezett - Budapesti királyi Törvényszék elnöke, majd tanácselnöke. 1886 végén a Budapesti királyi Ítélőtábla alelnökévé nevezték ki, ahol 1887. 01. 03-tól a büntető szakosztályt vezette. 1901 ben vonult nyugalomba. Aktív éveiben választmányi tagja volt a Magyar Jogászegyletnek, alelnöke az Országos Jogászgyúlés állandó bizottságának, bizottsági tagja a székesfőváros és Pest vármegye tövényhatósági képviselőtestületének. SZINNYEI, Magyar írók https://mek.oszk.hu/03600/03630/html/(2020. 07. 21.)
} 
ügyvédet, majd nyitja meg az alakulási gyúlést, amelynek székhelyén az ügyvédi kamara feláll. Ez amellett, hogy megfelelt a törvényi rendelkezéseknek - szerencsés egybeesés is volt, hiszen ő maga korábban ügyvédként működött, sőt mint fent említettem, ő volt a Budapesti Ügyvédegylet „ötletgazdája” és első alelnöke is. Sárkány József ünnepi nyitó beszédében már az üdvözlés során kifejezte a régóta várt törvény megszületése feletti örömét. Nem csupán azért, mert a szabályozás magas színvonalú, így kiállja a nemzetközi összehasonlítás próbáját, nemcsak amiatt, mert a törvényhozás végre felismerte az ügyvédi hivatás magasztosabb rendeltetését és szakított azzal a megközelítéssel, hogy az ügyvédeket az igazságszolgáltatás „,megrendszabályozandó” tényezőjének tekintse, hanem mert a rendtartásban ama nemes törekvések visszaigazolását látta, amelyért az ügyvédek - és különösen a pest-budai ügyvédek - évtizedek óta küzdöttek. „Az akkeori sejtelem, az, akekori ohajtásunk ime valósult! Az.1874-i törvényhozás bölcs elörelátással és méltánylattal érvényesitette egy részröl ą̊t, hogy ügyvédi jeles állást csak alapos készülltségü és jellemes férfiak foglalhassák el, más részroól érvényesitette ąt, hogy az ügyvéd magasztos hivatásában minden körülmények között teljes önállósággal járbasson el, - és mindenek felett érvényesitette az önkormányzati jogot, a függetlenség létfeltételét akekor, midön az ügyvédi testület legszentebb érdekeinek, és tekintélyének megóvását az erkölcsi solidaritás alapjára fektetve, az. ügyvédi kamara sajátkezeibe tette le. ${ }^{105} \mathrm{Az}$ ülést az ünnepélyes megnyitó beszéd után már a korelnök vezette, aki felolvasta a törvény vonatkozó rendelkezéseit, majd megalakították a kamarai tisztségviselők választásához szükséges szavazatszedő bizottságot. A közgyűlés magas létszámára tekintettel a szavazásra határidôt tűztek, az ülést pedig az eredmény kihirdetése végett február 22-én délután 4 órára elnapolták. A 22-én tehát újra összegyűlő fővárosi ügyvédi kar első rendelkezései között szerepelt, hogy az alakulás körüli „elözékeny figyelme és buฉgalmáert” küldöttségileg fejezze ki hálás köszönetét Sárkány Józsefnek, s erre rögvest meg is választották a küldöttséget. ${ }^{66}$ A szavazatszedő bizottság jelentése alapján a korelnök ismertette a választás eredményét, a BüK első elnöke Gbyczyy Gyula lett. Mivel ez alkalommal két választmányi póttag helyét nem sikerült betölteni, ezért február 28-án folytatódott az alakuló közgyúlés és a választás. ${ }^{67}$

A kamarai szervek tevékenységüket 1875 . március 1-jén kezdték meg. ${ }^{68}$ Az első rendes éves közgyűlést a jegyzőkönyvek szerint március 20-án tartották meg, a Jogtudományi Közlöny a hó végén, március 31-én jelentetett meg erről rövid beszámolót. ${ }^{69}$

Kevés szó szokott erről esni, de ama közszájon forgó vélekedéssel szemben, amely a Magyar Jogász Egylet jogelődjeként tekint a Budapesti Ügyvédegyletre, a valóság az, hogy a Budapesti Ügyvédi Kamara megalakulását követően az egylet feloszlatta magát és vagyonát javarészt a kamarának adta át. A tervek között valóban szerepelt, hogy esetleg jogászegyletté alakuljanak, de a Magyar Jogászegylet végül néhány évvel később, más célokkal jött létre, saját

\footnotetext{
65 A Budapesti Ügyvédi Kamara Közgyűlésének jegyzőkönyvei, 1875. 02. 20., KorsósNÉ, Az ügyvédi kamarák megszületése 93-95.

${ }^{66}$ A Budapesti Ügyvédi Kamara Közgyúlésének jegyzőkönyvei, 1875. 02. 22.

${ }^{67}$ Jogtudományi Közlöny 1875/9. 72.

68 KUN, A magyar ügyvédség története 339.

${ }^{69}$ Saját korábbi megállapításommal ellentétben, amelyben azt feltételeztem, hogy a kamarai irattár kolligátuma hiányos, ma már inkább azt tartom valószínűnek, hogy mivel a Jogtudományi Közlönyben megjelent beszámoló kelte nincs feltüntetve, a március 31-én megjelent lapszám egy 20-án kelt összefoglalót tett közzé az első közgyúlésről: „A budapesti ügyvédi kamara ma 3 órakor a megyeház. nagy termében tartá elsö közgyülését.” Jogtudományi Közlöny 1875/13. (03.31.) 116., KORSÓSNÉ, Az ügyvédi kamarák megszületése 96.
} 
előzményének pedig inkább a jogászgyúléseket tekintette. ${ }^{70} \mathrm{Az}$ 1875. év első felében az ügyvédegylet még múködött (pl. véleményt formált törvényjavaslatról) ${ }^{71}$ de a nyár folyamán megszűnt. Ennek okát a kortárs röviden úgy foglalta össze, hogy mint az köztudomású, az egylet elérte célját, ezért megszűnt létezni. ${ }^{72}$ Utolsó közgyúlését, amelyen a feloszlásról döntöttek, 1875. június 26-án tartotta. ${ }^{73}$ Ekkor az alapszabályaik értelmében (19. \h,) az egyleti vagyonról is rendelkeztek, és úgy döntöttek, hogy a meglévő alaptôkét és a segélypénztárt az egyéb még befolyó pénzzel együtt segélyalapítvánnyá átalakítva azzal bocsátják a Budapesti Ügyvédi Kamara rendelkezésére, hogy a létrehozott alapítvány a budapesti kamara betegség vagy egyéb szerencsétlenség következtében munkaképtelenné vált, vagy elszegényedett tagjainak illetve ezek özvegyeinek és árváinak segélyezésére szolgáljon. Az egyleti vagyon leltározására, annak részbeni kiárusítására stb. végrehajtó bizottságot küldtek ki, amely október közepére fejezte be munkáját. A belügyminiszter által jóváhagyott átadó határozat több mint 15.000 forintról szólt, és több kikötés mellett azt is tartalmazta, hogy a segélyezés során előnyt élvezzenek a külön mellékletben felsorolt volt egyleti tagok és családjuk, valamint hogy az alapítványi vagyont soha ne lehessen másra fordítani, mint magyar ügyvédek és hozzátartozóik segélyezésére. Az alapítvány részére átadott értékpapírokon és takarékkönyveken kívül természetben is kapott javakat a kamara, ugyanis az egyleti szakkönyvtár és a bútorzat legnagyobb része megmaradt, ezeket a kamara vette át. ${ }^{74}$

\section{A fôvárosi ügyvédi kar szerepvállalása a 19-20. század fordulóján}

A modern ügyvédi rendtartás megalkotása és a kamarák létrejötte cezúrát jelentett az ügyvédség történetében, hiszen ezt megelőzően csak fakultatív testületek voltak, a teljes ügyvédségre kiterjedő, törvényben rögzített autonómiával rendelkező szervezet hiányzott. A jogszabály által biztosított két fontos pillér, az autonómia és a szabad ügyvédkedés alapján az ügyvédség megindulhatott a modern professzionalizáció útján, amelynek hőskora a 19. század utolsó évtizedeire tehetô. A törvény rögzítette az ügyvédi kar jogszabály-kezdeményező illetve -véleményező hatáskörét, aminek nyomán körvonalazódni kezdett az a „küldetéstudat”, amellyel a modernizáció mellé álltak. Ennek további lendületet adott, ha úgy érezték, véleményük a jogalkotásban figyelmen kívül maradt, s nem mulasztották el ezt az igazságügyi kormányzatnál nehezményezni, bár a 19. század végén ez gyakran kimerült a jogrend szempontjából kisebb horderejű, inkább az ügyvédi megélhetést befolyásoló kérdések központba állításával. A hivatásszociológiai vizsgálatok szerint - amelyek fókuszában épp a fővárosi ügyvédi kar állt - a modernizációs szerepkör mellett a századfordulóra az ügyvédség már mint a jogállam védője identifikálta magát, s e társadalmi-hivatásbéli szerepük a 20. század első évtizedeiben erősödött, az egyre növekvő létszámúp ${ }^{75}$ és egyes egyéb kérdések mentén polarizált kart

\footnotetext{
${ }^{70}$ A Fővárosi Lapok rövid híre: „A budapesti ügyvéd egylet vasárnap d. e. tizenegy órakor rendkivüli köögyülést tart, melynek. fötárgya a válasz̨tmány inditványa lesz: az egylet feloszlatása, esetleg ıjogász-egyletté átalakitása tárgyában. ” Fővárosi Lapok, 1875/125. 568., Magyarország Jogászaihoz. Jogtudományi Közlöny 1879/52. 413-415.

${ }^{71}$ SCHNIERER Aladár: A büntetőtörvenyjavaslat Vlll-ik fejezete 166.

72 ZLINSZKY Imre: Jogtörténelmi vagy jog- és államtudományi társulat alapításáról 240.

73 A meghívót a Jogtudományi Közlöny is közzétette június 23-án megjelent számában. Jogtudományi Közlöny $1875 / 25.216$.

${ }^{74}$ Jogtudományi Közlöny 1875/44. 380.

75 A Budapesti Ügvyédi Kamara területén működő ügyvédek létszáma 1890 végén csaknem 900 (898) fő. Ügyvédek Lapja, 1891/12. 7.
} 
pedig össze is tartotta. Feladatuknak tekintették pl. a közszabadságok, a sajtószabadság, a bírói függetlenség mellett való kiállást, amikor úgy érzeték, ezek veszélybe kerülhetnek. ${ }^{76}$

Az ügyvédi hivatást, és különösen a budapesti ügyvédi kart, a 20. század elején ez az elkötelezettség jellemezte. Több helyütt kinyilvánították, hogy az ügyvédség szeizmográf, antenna, híd, amely felfogja és átvezeti, csatornázza a társadalom panaszait a jogalkotók illetve jogalkalmazók felé. Hangsúlyozták azonban, hogy a ,jogrend őre”-szerep és a társadalmi szerepvállalás nem jelenti azt, hogy az ügyvédek politikai áramlatokra ülnének fel, sőt elvárták a szakmai múködésben a pártsemlegességet, azt, hogy az ország törvényei, a sérelmet szenvedők mellett politikai irányzatoktól mentesen álljanak ki. ${ }^{77}$

Mindehhez erős alapot jelentett nemcsak a már említett szabályozási háttér és autonóm szervezet, hanem az a tisztelet is, amellyel a kar az ügyvédség múltja és a hivatásnak tekintélyt adó nagy elődök felé fordult. Már 1893-ban arról döntött a Budapesti Ügyvédi Kamara, hogy feltárja és összegyűjti az ügyvédség múltját jelentô emlékeket. ${ }^{78}$ A cél egyrészt egy millenniumi kiállítás összeállítása volt, majd az összegyûlt anyagból a magyar ügyvédség történetének megírása, amelyekből csupán az első valósult meg. ${ }^{79}$ Noha az erre felkért Sík Sándor ügyvéd csak az anyag összegyújtését és katalogizálást tudta elvégezni, a századforduló környékén két ügyvéd szerző is nagyobb lélegzetű munkát írt az ügyvédség történetéről (Kun Lás₹̨ó, Králik Lajos). ${ }^{80} \mathrm{~A}$ századfordulót követő időszakban különösen jellemzővé váltak az évfordulós megemlékezések, a történeti apropójú ünnepi közgyúlések, amelyek lehetőséget teremtettek a hivatásról való elmélkedésre, az ügyvédi kar szerepének meg- illetve újrafogalmazására. ${ }^{81}$

\section{Felhasznált források és irodalom}

1874. évi XXXIV. törvénycikk az ügyvédi rendtartás tárgyában https:/ / net.jogtar.hu/ezer-ev-torveny?docid=87400034.TV (2020. 07. 02.)

A m. kir. igazságügyministernek 1874. decz. 28-án 35365. sz. a. valamennyi kir. bíróság és ügyészség vezetőjéhez intézett körrendelete: az ügyvédi kamarák számának s székhelyeinek megállapítás a tárgyában. Magyarországi Rendeletek Tára, 1874, 671-672.

A budapesti ügyvédi egylet által Pesten 1868. évi január hó 26-án tartott közgyűlés jegyzökönyve. Jogtudományi Közlöny 1868/7. 49-50.

A budapesti ügyvédi egyletnek a m. kir. miniszterium által jóváhagyott alapszabályai. Jogtudományi Közlöny 1867/33. 185-188.

A Budapesti Ügyvédi Kamara Közgyűlésének jegyzőkönyvei 1875 - 1902. Budapesti Ügyvédi Kamara Irattára (jelzet nélkül)

BÓNIS György: A jogtudó értelmiség a Mohács előtti Magyarországon. Budapest 1971

\footnotetext{
${ }^{76}$ NAVRATIL, A jogászi hivatásrendek története Magyarországon 69., 73-75., 80., 102-103., KorSÓSNÉ, Az ügyvédi kamarák megszületése 163-168.

77 NAVRATIL, A jogászi hivatásrendek története Magyarországon 104-107.

${ }^{78}$ FÖLDVÁRI Béla: A magyar ügyvédség és a magyar közélet 3. (Pap József előszava)

${ }^{79}$ RÉTI, A jogi képviselet szerepe és a ius patrium 417-418.

80 Sik Sándor (1853 - 1900) budapesti ügyvéd, hosszú időn keresztül a Budapesti Ügyvédi Kamara titkára. Kun Lás₹ló (1840 - 1896) 1869-től gyakorló ügyvéd Budapesten. Az ügyvédség történetéről szóló munkája 1887-től kezdődően folytatólagosan füzetekben, majd 1895-ben kötetbe foglalva jelent meg. SzINNYEI, Magyar írók https://mek.oszk.hu/03600/03630/html/k/k13100.htm, https://mek.oszk.hu/03600/03630/html/s/s24001.htm (2020. 07. 02.)

${ }^{81}$ NAVRATIL, A jogászi hivatásrendek története Magyarországon 105.
} 
Életképek 1847/20.

Elnöki jelentés a budapesti ügyvédi egyletnek 1868-ik évi működéséről. Jogtudományi Közlöny 1869/6. 41-42.

FÖLDVÁRI Béla: A magyar ügyvédség és a magyar közélet. Budapest 1920

Fővárosi Lapok 1875/125., 1890/263.

Javaslat az ügyvédi rendtartás tárgyában. Közzéteszi a M. kir. Igazságügy-ministerium. Pest 1871

Jogtudományi Közlöny 1866/20., 1867/33., 1867/36., 1867/41., 1867/42., 1867/43., 1867/45., 1867/52., 1868/1., 1868/5., 1868/6., 1868/7., 1868/21., 1868/38., 1868/39., 1868/40., 1869/6., 1875/1., 1875/9., 1875/13., 1875/18., 1875/25., 1875/26., 1875/28., 1875/44., 1879/52., 1896/38.

KAILL Sándor: Ügyvédreform törvényjavaslatban előterjesztve. Budapest 1848

KORSÓSNÉ DELACASSE Krisztina: Az ügyvédi kamarák megszületése Magyarországon. Budapest - Pécs 2012

KUN László: A magyar ügyvédség története politikai s társadalmi tekintetben, a legrégibb időktől máig, párhuzamban a birósági szervezet fejlődésével. Budapest 1895

LIERMANN, Hans: Richter, Schreiber, Advokaten. München 1957

MARKos Olivér: Ügyvédi tisztesség és kari tekintély. Polgári Jog 1927/6. 133-137., Polgári Jog 1927/7. $161-167$.

MÁTHÉ Gábor: A magyar burzsoá igazságszolgáltatási szervezet kialakulása 1867 - 1875. Budapest 1982

NAVRATIL Szonja: A jogászi hivatásrendek története Magyarországon (1868/1869 - 1937). Budapest 2014

PALUGYAY Imre, ifj.: Ügyvédek. Korszerű tervezet ezeknek ügyében, Buda 1841

RÉTI László: A jogi képviselet szerepe és a ius patrium. In: MÁTHÉ Gábor (szerk.): A magyar jog fejlődésének fél évezrede. Werbőczy és a Hármaskönyv 500 esztendő múltán. Budapest 2014

SCHNIERER Aladár: A büntetőtörvényjavaslat VIII-ik fejezete. Jogtudományi Közlöny 1875/18. 165-167.

SIEGMUND Vilmos (szerk.): A Budapesti ügyvéd-egylet évkönyve 1869. és 1870. évre. Pest 1870

SIEGMUND Vilmos (szerk.): A Budapesti ügyvéd-egylet évkönyve 1871. évre. Pest 1872

SIEGMUND Vilmos: A budapesti ügyvédi kamara alakulása. Magyar Themis, 1875/7. 1.

Sík Sándor (szerk.): A magyar ügyvédi kar történeti kiállításának katalogusa. Budapest 1896

Az MTA székháza. (SISA József: A Magyar Tudományos Akadémia - Séta a székházban, Budapest 2015 munkája nyomán) https://mta.hu/hatteranyagok/az-mta-szekhaza-105350 (2020. 07. 22.)

SZINNYEI József: Magyar írók élete és munkái. https://mek.oszk.hu/03600/03630/html/

TAKÁCs Dániel: Alternatív könyvtárak, avagy egy lehetséges jövőkép. A Budapesti Ügyvédi Kamara könyvtárának stratégiai terve (szakdolgozat). 2011 http://mek.oszk.hu/11300/11342/11342.pdf (2020. 07. 17.)

Törvényszéki Csarnok 1866/35., 1866/76., 1867/63., 1867/69., 1867/71., 1867/72., 1867/79. , 1868/41., 1869/7., 1869/11., 1869/18.

Törvénytudományi múszótár, Pest 1843 http://mek.oszk.hu/05200/05267/05267.pdf (2020. 07. 19.)

TÓTH Lajos: A budapesti ügyvédi kamara alakulásáról. Jogtudományi Közlöny 1875/1. 7-8.

TÓTH Lőrinc: Ügyvédi állapotok. Röpirat ügyvédi érdekben. Pozsony 1848

Ügyvédek Lapja 1891/12., 1894/13.

VARGA Endre: A hivatásos ügyvédi osztály kialakulása. A kötelező ügyvédi vizsga bevezetése 1769-ben. In:

Emlékkönyv Domanovszky Sándor születése hatvanadik évfordulójának ünnepére. Budapest 1937, 625-642.

ZLINSZKY Imre: Jogtörténelmi vagy jog- és államtudományi társulat alapításáról. Jogtudományi Közlöny 1875/28. 240. 